\title{
9 The feminine face of the African Commission on Human and Peoples' Rights
}

\author{
Reine Alapini-Gansou
}

\section{Introduction}

The African Commission on Human and Peoples' Rights (hereafter African Commission or ACHPR) was established on May 28, 1987, ${ }^{1}$ after the African Charter on Human and Peoples' Rights (hereafter African Charter) entered into force in 1986 (African Charter, 1981). This Charter, together with its implementation mechanism (i.e., the African Commission), remains, at the African continental level, a symbol of the need to regionalize the promotion and protection of human rights systems as advocated during the 1980s by doctrine, emerging civil society, ${ }^{2}$ and political actors. The African Commission is intended to be an extension and strengthening of the universal human rights system on the African continent and in line with other regional systems. ${ }^{3}$

In this respect, the African regional system has often been compared to other regional systems, particularly the European and Inter-American regional systems. The Asian regional system is gradually being established and has not yet reached the level of consolidation required. ${ }^{4}$ Like the United Nations Charter, which promotes the basic principles for promoting and respecting human rights, the African Charter contains 68 provisions (African Charter, 1981). Civil and political rights are embodied in the first generation; the economic, social, and cultural rights are found in the second generation; and solidarity rights are in the third generation. However, unlike other international treaties, the third generation of rights has not been adequately enumerated in the Charter. ${ }^{5}$

The African Commission, the first African human rights treaty body, was established under Articles 30-36 of the African Charter and is composed of 11 members chosen from among African personalities of the highest reputation (African Charter, 1981). The Assembly of Heads of State and Government elects the members, who serve six-year terms. ${ }^{6}$ Members are chosen for their "high morality, integrity, impartiality and competence in matters of human and peoples' rights; particular consideration being given to persons having legal experience" (African Charter, 1981, Art. 31). Further, the members "serve in their personal capacity" (African Charter, 1981, Art. 31). Under Article 45 of the African Charter, the African Commission has the mandate to promote and protect human and peoples' rights under conditions described by the Charter 
(African Charter, 1981). The Commission is also charged with interpreting the provisions of the Charter at the request of States Parties or recognized African institutions and organizations (African Charter, 1981, Art. 45). Furthermore, it performs any other tasks entrusted by the Assembly of Heads of State and Government (African Charter, 1981).

As a body whose mission is to promote and monitor human rights across the African continent, the ACHPR must set an example by rigorously applying the rules and respecting stakeholders' wishes. Indeed, the logic of political actors is often different from those of human rights experts and technicians, even when states commit themselves under international legal instruments to promote equal rights. Thus, from the perspective of the right to non-discrimination provided in Article 2 of the African Charter and to hold the Commission to a high standard, non-governmental organizations (NGOs) and civil society organizations (CSOs) quickly raised the issue of the equitable representation of women within the African Commission. These civil society groups include Solidarity for African Women's Rights (SOAWR), the African Women's Development and Communication Network (FEMNET), and Femmes Africa Solidarité, which were, and still are, active in lobbying the African Commission on gender issues (Open Society Initiative, 2009). The lobbying efforts by these actors were essential for achieving the equitable representation of women both in political decision-making bodies and in the states' judicial positions.

This chapter aims to analyze the trajectory of the African Commission in terms of women's representation and how women members of this human rights institution have progressively fulfilled its several mandates. This focus considers the fact that the African Commission as a quasi-judicial body remains the oldest model of the African human rights system.

This chapter outlines the steadily increasing trend of women's representation in the African Commission and the reasons for such changes. The first part analyzes this trend and the representation of women within the ACHPR, noting that initially this representation was non-existent in terms of effective participation and that, progressively, the trend changed. In addition, it further examines the importance of women's representation as a way of advancing human rights in the region. The second part then highlights some striking examples of the role that elected women of the African Commission have played over time. These examples include two essential mechanisms with mandates that have been constantly held by women and are concrete demonstrations of the valuable work women representatives have carried out and developed within the system: the Special Rapporteur on the Rights of Women in Africa and the Special Rapporteur on Human Rights Defenders in Africa. Finally, the chapter argues that although much has been achieved in terms of representation, work must be done to continue and expand upon this representation. Thus, some strategies for ensuring the continuation of the upward trend in women's representation are briefly discussed.

The present chapter aims to present a critical conceptual overview of the African Commission based on a legal analysis of the available literature on the topic, including documents, reports, articles, and papers from diverse human 
rights bodies and their actors. Furthermore, it draws from this writer's experiences as a human rights actor with a personal and professional background in the African human rights systems. The chapter highlights some ways that the Commission has implemented its objective of expanding women's participation within the system and the region, including gender-balanced representation requirements for the election of its commissioners; civil society participation in the work of the Commission, especially those segments that advocate for gender equality; the adoption of the Protocol to the African Charter on Human and Peoples' Rights on the Rights of Women in Africa (the Maputo Protocol); and the creation of a special procedure (the Special Rapporteur on Human Rights Defenders in Africa) to specifically address women's rights in the region. Each of these channels is further discussed throughout the text.

\section{The representation of women within the ACHPR: An almost successful challenge}

\section{The African Commission: A short history}

At the time of its creation in May 1987, the African Commission was marked by the same shortcoming as that of other institutions that predated it-namely, the absence of women in the spheres of professional life. As a result, the African Commission initially suffered from an absence of women among its commissioners. Despite changes that will be discussed, the secular struggle of feminists to change preconceived ideas about women's role in professional life continues, and women activists are still working tirelessly on these topics. The Beijing Conference $^{7}$ and its aftermath are also relevant to this matter, given how the conference positioned women's issues on a global platform.

After the first elections of the African Commission members in 1987, the institution was led by two men: the late Commissioner Isaac Nguema, first chairperson of the African Commission, and its vice-chairperson, Commissioner Ibrahim Ali Badahoui el Cheikh (African Commission, n.d.a). The African Commission's first activity report in 1988 did not include any women (African Commission, n.d.b). It was in June 1993, during the 29th Summit of the Assembly of Heads of State and Government of the Organisation of African Unity, that Mrs. Vera Valentina De Melo Martins Duarte was elected as a member of the African Commission, becoming the first woman in the institution alongside her male peers (Organisation of African Unity, 1994).

During the internal election that followed, as set out by Article 42 of the Charter, Commissioner Duarte became the vice-chairperson of the African Commission, alongside Chairperson Mr. Youssoupha Ndiaye, from 1997 through 1999 (African Commission, n.d.b). ${ }^{8}$ Mrs. Duarte's expertise in human rights and international law, coupled with her role as a Supreme Court judge in Cabo Verde and being the first woman elected to the African Commission, was determinant in her earning this position (Lima-Neves, n.d.). ${ }^{9}$ Two years later, Mrs. Duarte was joined by Mrs. Julienne Ondziel-Gnelenga, a Congolese lawyer and seasoned 
women's rights activist who worked as a member of the Women, Peace, and Security Network Africa (Gutto, 2001). Mrs. Ondziel-Gnelenga was elected for a six-year term in June 1995 in accordance with the term guidelines in Article 36 of the African Charter (Malmstrom \& Oberleitner, 1996).

In April 1998, during the 23rd session of the African Commission at Banjul in The Gambia, Mrs. Ondziel-Gnelenga was announced as the Special Rapporteur on the Rights of Women in Africa (African Commission, n.d.b). Her functions as Special Rapporteur on the Rights of Women in Africa were confirmed by Resolution 38 (XXV)99, adopted during the 25th Ordinary Session of the African Commission held in Bujumbura, Burundi, in 1999 (African Commission, n.d.b). She served as vice-chairperson of the African Commission under the chairmanship of Commissioner Mr. E. V. O. Dankwa of Ghana from November 1999 until October 2000 (African Commission, n.d.b). Thus, from 1995 to 2000, Commissioners Duarte and Ondziel-Gnelenga were the only two women at the African Commission. These developments show that the Beijing recommendations and the various resolutions regarding the adoption of a gender approach were not fully implemented without difficulty. ${ }^{10}$

After Commissioner Duarte's election in 1993, women's representation on the Commission slowly increased. In 2002, 4 out of 11 members of the African Commission were women; ${ }^{11}$ this number increased to 5 in $2003 .{ }^{12}$ In 2005, there were still five women on the Commission, as two women and two men were elected to replace the commissioners whose terms of office were expiring. ${ }^{13}$ During the elections held during the 2007 African Union (AU) Summit and because of lobbying pressure by $\mathrm{NGOs}$ and $\mathrm{CSO}$, African member states proposed a number of women candidates, ${ }^{14}$ a wake-up call for gender equality on the Commission. As a result, in 2007, there was a surge in women's representation on the African Commission: Women represented a strong majority of the membership—seven women to four men. ${ }^{15}$

In 2009, Angela Melo was elected for a three-year term. ${ }^{16}$ In 2011, after the resignation of Commissioner Fayek, three women and two men were elected; ${ }^{17}$ then, in 2013, two women and two men were elected. ${ }^{18}$ In 2015, two women and one man were elected, ${ }^{19}$ and in 2017 , the election resulted in two women and two men being on the Commission. ${ }^{20}$ Table 9.1 shows the shifting gender composition of the Commission.

The African Union now takes into account the principles of equitable geographical distribution and balanced representation of men and women in the election of commissioners (African Commission, n.d.a; African Union, 2016a). From 2011 to 2020, of the 11 members of the African Commission, at least 6 positions have been filled by women. The women currently on the Commission are Jamesina Essie L. King from Sierra Leone, Lucy Asuagbor from Cameroon, Maria Teresa Manuela from Angola, Maya Sahli-Fadel of Algeria, Soyata Maiga from Mali, and Sylvie Zainabu Kayitesi from Rwanda (African Commission, n.d.b).

Looking at Table 9.2, it is important to recall how the members of the ACHPR have since made a judicious application of the African Charter concerning the 
Table 9.1 Gender composition of the African Commission 1987-2019*

\begin{tabular}{llc}
\hline Year & Women & Men \\
\hline 1987 & 0 & 11 \\
1989 & 0 & 11 \\
1991 & 0 & 11 \\
1993 & 1 & 10 \\
1995 & 2 & 9 \\
1997 & 2 & 9 \\
1999 & 4 & 7 \\
2001 & 4 & 7 \\
2003 & 5 & 6 \\
2005 & 5 & 6 \\
2007 & 7 & 4 \\
2009 & 5 & 6 \\
2011 & 7 & 4 \\
2013 & 6 & 5 \\
2015 & 7 & 4 \\
2017 & 7 & 5 \\
2019 & 6 & 5 \\
\hline
\end{tabular}

${ }^{*}$ Gender composition measured after elections from the second ordinary session of that year.

Table 9.2 Women in chairperson positions: Consecutive years of leadership in the ACHPR

\begin{tabular}{lll}
\hline Year & Chairperson & Vice-Chairperson \\
\hline $2003-2005$ & Salimata Sawadogo & Yassir Sid Ahmed El Hassan \\
$2005-2007$ & Salimata Sawadogo & Yassir Sid Ahmed El Hassan \\
$2007-2009$ & Sanji Monageng & Angela Melo \\
$2009-2011$ & Reine Alapini-Gansou & Mumba Malila \\
$2011-2013$ & Catherine Dupe Atoki & Sylvie Zainabu Kayitesi \\
$2013-2015$ & Sylvie Kayitesi Zainabo & Mohamed Bechir Khalfallah \\
$2015-2017$ & Faith Pansy Tlakula & Soyata Maiga \\
$2017-2019$ & Soyata Maiga & Lawrence Mute \\
\hline
\end{tabular}

election of the members of the Bureau. According to Article 42 of the Charter, "the board members shall be elected for a renewable term of two years" (African Charter, 1981). However, members assume that no one should lead the African Commission ad vitam aeternam, ${ }^{21}$ even if Article 42 of the Charter does not prescribe any limitation of mandates. Except for Commissioners Sawadogo and Ahmed El Hassan, who both served two consecutive terms because, in the exceptional circumstances, no election was held, all board members have served a non-renewable two-year term since 2007. This is an important example of the democratic alternation that the members of the African Commission should continue to apply. 


\section{Mechanisms and strategies that contributed to increasing women's participation and representation in the African Commission}

This change in trends and the increase in women's participation cannot be attributed to only one or a few mechanisms. They are due to a combination of complex acts taken by the Commission with the participation of several actors. For the purpose of this chapter, three of these instruments deserve emphasis.

The first point is the adoption of legal requirements with gender specifications. Since the creation of the African Commission, states have adopted two possible attitudes toward the representation of women: States either comply with their national laws, reinforced by African Union rules on gender compliance in elections, or take strict account of vacancy notices that now clearly indicate the number of candidates by gender for each region of the continent. The second approach is an obligation under the African Union system to ensure that candidates are diverse by gender and by region.

As a human rights body entrusted to implement the Maputo Protocol, the African Commission, alongside other actors like the Special Rapporteur on the Rights of Women in Africa, lobbies for and monitors several female candidates to ensure that women are represented in the African Commission. ${ }^{22}$ During each African Union summit, the chairperson of the Commission, previously Commissioner Soyata Maiga, followed by Commissioner Lucy Asuagbor, is present for the record beside African women institutions and women activists to ensure that gender issues are discussed at the summits. The fact that women occupy these positions helps to encourage gender-related discussion. The African Union system requires details on the number of candidates by gender and region. For example, the Maputo Protocol requires in Articles 8 and 9 "that women are represented equally in the judiciary and law enforcement organs" and that "women are represented equally at all levels with men in all electoral processes" (African Union, 2003). Further, the African Union Gender Policy explicitly calls for equal gender representation in decision-making through the AU Parity Principle (African Union, 2009, pp. 13-16). ${ }^{23}$

Failure to achieve a fair representation of female and male judges risks the possible postponement of the elections; today, we observe that this right, which belongs to female candidates, is being undermined..$^{24}$ Even if implementation is slow, these gender inclusion requirements represent efforts at the level of the African Union that must be encouraged and strengthened to ensure equity and justice.

Another tool that contributed to the increase of women's participation was the Maputo Protocol and the several activities related to its implementation. ${ }^{25}$ The Maputo Protocol, which entered into force on November 25, 2005, echoes many of the same provisions contained in the United Nations Convention on the Elimination of All Forms of Discrimination against Women (CEDAW), but it has further developed the mechanisms for the protection of women and takes into account issues unique to the region, such as child marriage and female genital mutilation (FGM) (African Union, 2003). The Protocol addresses the effects 
that culture and tradition have on women's rights (African Union, 2003). In sum, the Protocol is a strong framework for ensuring the rights of women in the African continent.

The Protocol is a treaty body in the African context and establishes obligations toward states that intersect with obligations established in other international documents, such as CEDAW and the Convention on the Rights of the Child (CRC), for instance. Therefore, it expands and reinforces the regional level states' obligations toward women and reinforces states' accountability for specific women's rights violations. The Commission is responsible for supervising states' implementation of the Maputo Protocol and offers guidance on the interpretation and application of rights. Article 26, for instance, obliges states to submit reports every two years on the domestic steps taken to implement and give effect to the Protocol (African Union, 2003).

By addressing gender-based discrimination, reducing the gap between men and women in access and enjoyment of rights, and creating mechanisms to hold states accountable for violations, the Maputo Protocol restated the importance of equality between men and women in the African region. It opened the path to higher professional positions for women. It also reaffirmed the importance of women's rights for the Commission and as a central point to be promoted among the states. Since women's rights are important to the Commission, an increase in women's representation on the Commission is also important. Thus, the Maputo Protocol is both the result of and the reason for the expansion of women's presence on the African Commission.

In addition, perhaps one of the most effective and relevant mechanisms for ensuring women's representation on the Commission and other organs is the participation of human rights defenders, civil society actors, NGOs, and gender equality activists. These actors played and continue to play an important role in the implementation of the Commission's mandate and of the values enshrined in the African Charter. Human rights are the result of people's suffering and the struggle to resist oppression and discrimination. Therefore, civil society is essential for pressuring political actors and institutions to change practices and attitudes toward a more equal and justice world.

For instance, the International Commission of Jurists ${ }^{26}$ was alongside the African Commission from the beginning of its mandate and provided technical support. ${ }^{27}$ Many other civil society actors were also present on the Commission, and their work gradually crystallized around the public sessions of the African Commission. ${ }^{28}$ The Commission resolved to allow NGOs to seek and obtain observer status, which bolstered them in encouraging women's participation and representation in the Commission. ${ }^{29}$ To date, the results of the various NGO forums that have been held in the lead-up to each session of the African Commission are commendable. The constant and sustained presence of women in the African Commission results from this civil society pressure and lobbying, which resonated to the African Union summit. Civil society actors secured their places in the African Union Commission by obtaining observer accreditation for the African Union summit. ${ }^{30}$ Indeed, the very creation of the Maputo Protocol 
resulted from civil society pressure aligned with the activism of the Special Rapporteur on the Rights of Women in Africa (African Union, 2016b).

There is no one exclusive feature that made it possible for the Commission to increase women's participation. It was a process shaped by political articulation, struggle, achievement of rights, and participation by multiple groups. Certainly, the election of the first woman, Vera Duarte, exemplifies this combination. Her election opened the path for more women to engage in the work of the Commission. While still a commissioner, Duarte organized a seminar in Togo, where she proposed that the African Charter should have a complementary document to address women's rights (Nos Genti, 2012). Her proposal was accepted and adopted by the African Commission. Subsequently, a commission was created that included different human rights actors and organizations, such as the International Commission of Jurists, responsible for working on the project of this document. Finally, it resulted in the creation and eventual approval of the Maputo Protocol (Nos Genti, 2012). This example shows how those mechanisms act together and how representation created a circle of empowerment. The fruits of Duarte's election and of her prioritization of women's rights on the agenda of the Commission were the protection of and respect for women's rights, the emancipation and empowerment of other women, and consequently, more women's representation.

\section{Women's representation in the African Commission: A human rights achievement}

The women elected to the African Commission have outstanding personal and intellectual skills combined with a notable set of experiences. The members of the African Commission do not hold a permanent position and therefore continue their professions in their home countries while serving the Commission, ${ }^{31}$ which highlights the level of commitment and responsibility to the human rights causes that these professionals have. Women members of the African Commission, who work full-time in their countries, come from strongly intellectual backgrounds. While maintaining their own careers, as members of the African Commission the women must properly apply and implement the Charter and Article 45 through human rights promotion and protection activities (African Charter, 1981), which they must report upon to each ordinary session under Rule 72 of the Rules of Procedure of the African Commission (African Commission, 2010).

Beyond their legal expertise, most women elected to the African Commission are highly competent in specific human rights issues. For example, they have expertise in the rights of Indigenous peoples, the rights of people living with $\mathrm{HIV}$, the rights of people in detention related to police action, the rights of people of African descent, the rights of people living with disabilities, and the rights of older persons. ${ }^{32}$ Further, these varied issue-based human rights foci are used to implement economic, social, and cultural rights regarding extractive industries, the death penalty in Africa, and many other discrete issues facing the continent. 
Therefore, the Commission now profits from these valuable professionals, who were once excluded from this field. The African Commission is composed of women sitting judges; women from the prosecutor's office; and lawyers with extensive expertise in all areas of human rights law, international law, and women's rights in particular. Some are also academics with expertise in criminal law, criminal procedure, and human rights trials. ${ }^{33}$ All these women bring their professional acumen and can apply their experiences and knowledge to the work of the Commission.

Women commissioners certainly offer a wider range of highly qualified professionals to the Commission, but most importantly, they diversify points of view, help to expand the topics of issues approached, and offer new inputs and problem-resolution methods throughout their representation, without which it is impossible to build human rights for all. As in many other discriminatory dynamics, gender-based discrimination is systemic and present in the whole society and political structure. Therefore, gender-based discrimination has consequences for the law as well. For decades, men's views, experiences, and ideas have dominated the legal-judicial work and led to a system designed by and for men. This design becomes per se exclusive of and blind to women's problems, perspectives, and needs (Olsen, 1990). A system created, articulated, and operated mainly by and for men will never represent and properly address issues uniquely faced by women.

To address this discrimination, human rights systems, either international or regional, were created to achieve equality among people and to be applied universally. Therefore, those rights should be created, applied, and operated with the presence and representation of as great a diversity of experiences, especially regarding gender, as is possible. This representation is the only means by which the rights of all, including women, will be preserved and protected equally.

When women start to participate more actively in developing human rights bodies such as the African Commission, not only do those professionals gain from their participation, but the whole system gains. Women's presence guarantees that issues related to women's experience and needs will receive due attention and consideration. For instance, matters that affect women specifically in more oppressive ways, such as child marriage, FGM, human trafficking for sexual exploitation, absence of reproductive rights like safe abortion and forced sterilization, and sexual abuse are included in the agenda of the Commission more vehemently. Similarly, even though the African Union has addressed the fact that issues such as housing, access to decent work, and education, for example, affect all, women and girls are still affected more negatively than men (African Union, 2018). For instance, in the context of armed conflicts, women tend to suffer greater deprivations (African Union, 2018). In many cases, women face multiple and intersectional discrimination based on other grounds, such as their health condition, language abilities, or geographic location, along with gender discrimination.

Further, women's presence is important for initiating changes in sexist practices and harmful gender-based stereotypes embedded within the culture, costumes, practices, political context of states, and political actors and 
is thus equally reproduced in international bodies. Women's presence in the Commission through the decision-making and political articulation processes, for instance, is essential for challenging the tendency of discriminatory practices to pass as elements of culture, religion, or normality. In addition, women become the protagonists of their own history and advance their own rights rather than depending on the benevolence of those in charge. Further, women's presence on the Commission sends a message to all women of the continent: They are represented by people who know their struggle and understand their needs. The representation is a source of inspiration to young girls, who now see themselves occupying those important positions and can feel motivated to seek the same path. Representation is a process that leads to empowerment.

As a human rights body, the African Commission is most efficient when all the rights enshrined in the Charter are realized equally. An essential part of that means guaranteeing to women and girls, who have many of their rights violated for reasons of gender-based discrimination or experience harsher violations, the achievement of the full enjoyment of rights free of discrimination. This cannot be accomplished solely by men in the Commission and in the institutions that are supposed to secure this cause. In sum, although women's presence in the African Commission is in itself a concrete result of the struggle for equality, those women put their skills at the service of African populations on a daily basis in the fight to continue to advance human rights. Their action has enabled the African Commission to achieve a more diverse, inclusive, and representative board, thereby varying the ways to realize many of its objectives. In this way, many of the Commission's special procedures to implement these objectives have been led by women. In this regard, the following section will highlight two of these special procedures ${ }^{34}$ that have reinforced the female face of the African Commission.

\section{Model of the female face of the African Commission: Rights of women and rights of human rights defenders in Africa}

As demonstrated earlier, for several years after its establishment in 1987, the African Commission suffered from the total absence of women in its membership; but in 1993, the trend began to change. The women who were subsequently elected put their expertise, sense of initiative, and skills at the service of the African populations and of the African Commission itself. Due partly to the work of these women, the African Commission has achieved visibility as a leading human rights body within Africa. Women lead many of the special mechanisms currently evolving within the African Commission, including areas addressing rights of women, prisoners, people with disabilities, people with HIV, environmental protections, and advocacy against the death penalty. ${ }^{35}$ However, only two special mechanisms will be highlighted in this section. The Special Rapporteur on Rights of Women in Africa will first be examined because of its precedence in establishing the African Commission's special procedures. The Special Rapporteur on Human Rights Defenders in Africa will then be examined 
because of its importance in the world generally and specifically in Africa, as those called human rights defenders are people on the front line of danger and fight courageously against political actors and other perpetrators of human rights violations. Since their creation, these mandates have been occupied mostly by women.

In addition to the mechanism of the Special Rapporteur on Rights of Women in Africa led by Lucy Asuagbor (at the time of writing), the following special mechanisms are all ones for which women hold the mandates: the Special Rapporteur on Detention and Prisons in Africa led by Maria Teresa Manuela; the Working Group on Death Penalty in Africa led by Zainabo Sylvie Kayitesi; the Special Rapporteur on Refugees, Asylum Seekers, and Internally Displaced Persons in Africa led by Sahil-Fadel; the Working Group on Human Rights and HIV in Africa led by Soyata Maiga; the Working Group on Indigenous Populations and Communities in Africa, also led by Soyata Maiga; the Special Rapporteur on Freedom of Expression and Access to Information led by Faith Pansy Tlakula; and the Working Group on Economic, Social and Cultural Rights led by Jamesina Eddie L. King (African Commission, n.d.c). ${ }^{36}$ Thus, the representation of women, in terms of both number and intellectual qualification, in addition to meeting regional and international gender requirements and standards, has shown itself successful in face of the work provided in each of these mechanisms. ${ }^{37}$

\section{Special Rapporteur's mechanism on the rights of women in Africa: A successful model of women's activism}

As one of the oldest mechanisms of the African Commission, the Special Rapporteur's Mechanism on the Rights of Women in Africa was adopted at its 23rd Ordinary Session in Banjul, in 1998 (African Commission, n.d.c). The mandate of the Special Rapporteur on the Rights of Women in Africa is to assist African governments in the implementation of the Maputo Protocol through national mechanisms and legislation; undertake promotion and protection missions throughout the continent and report back to the African Commission; initiate and develop tools and studies on the situation of women's rights in Africa; and keep contacts with similar mechanisms around the world (African Commission, n.d.c). ${ }^{38}$ This resolution has been renewed several times to respond to changing needs and improve the effectiveness of the mechanism. ${ }^{39}$ This renewal process applies to all the special procedures created within the African Commission, although this mechanism was one of the first to be renewed and is one of the oldest special procedures in Africa. ${ }^{40}$

The initiative to create the mandate coincided with the preparations for the 1995 Beijing Conference, whose action plan, recommendations, and lobbying surrounding the implementation of the United Nations CEDAW ${ }^{41}$ subsequently promoted the adoption of the Protocol to the African Charter on the Rights of Women in Africa. The mechanism of the Special Rapporteur on the Rights of Women in Africa, led by Mrs. Julienne Onziel-Gnelenga in 1998, promoted the adoption of the Maputo Protocol ${ }^{42}$ with the support of African civil society 
(African Commission, n.d.c). The effective implementation of the Protocol has been carried out gradually under the African Commission's supervision pursuant to Article 26 of the Protocol. ${ }^{43}$ Since its creation, this mechanism has been carried out by women.

At the completion of Julienne Onziel-Gnelenga's term with the Commission, the mandate for the Special Rapporteur on Rights of Women in Africa was carried out from 2001 to 2007 by Commissioner Angela Melo. ${ }^{44}$ The mechanism then made significant progress under the leadership of Commissioner Soyata Maiga from 2007 through 2015 (Durojaye, 2018), particularly with her initiatives developing General Comments on many provisions of the Maputo Protocol. ${ }^{45}$ She also pushed for significant reform of the African Commission resolution on reporting within Article 62 of the Charter and Article 26 of the Maputo Protocol while she was working for the full implementation of the Protocol (Durojaye, 2018). Thanks to her efforts and the adoption of General Comments, the States Parties have specific direction on how to implement and apply various articles in the Maputo Protocol. Commissioner Lucy Asuagbor has been in office as Special Rapporteur on Rights of Women in Africa since 2015 (African Commission, n.d.c).

Increasingly, the presence of the Special Rapporteur on Rights of Women in Africa at all African Union summits has influenced the African Union by raising gender issues at the summits. The Special Rapporteur has involved women's associations, such as Women in Law and Development in Africa (WiLDAF), to work alongside the African Commission (Wandia, 2004). This participation has also led to an increasing number of women joining other bodies of the African Union, a presence that has been felt in reforms since the African Union's creation. The increased presence of women was also made possible by the Gender Is My Agenda Campaign, which lobbied political actors before and during the elections of African Commission members. ${ }^{46}$

While advocating for African integration through development, the heads of state and governments within the African Union system have not overshadowed the necessary resolution of the gender issue. The proactive role that the Special Rapporteur plays helps ensure that gender issues remain at the forefront of the African Union's policies and discussions. Without gender representation in the African Union system, development efforts in other instances would undoubtedly be undermined. For example, the Commission of the African Union, as the African Union's secretariat in accordance with the Constitutive Act, considers equitable geographical distribution. Additionally, it now considers a balanced representation of men and women in all technical and political bodies of the Union regarding elected members (African Union, 2016a). This shift to inclusion was in response to instructions from the African Union Assembly in an Executive Council decision in 2016 (African Union, 2016a).

These principles of geographic distribution and gender representation also apply to the election of commissioners and the judicial bodies ${ }^{47}$ In support of this initiative, the Executive Council suspended the election of a judge for the African Court on Human and Peoples' Rights for lack of female candidates for the Southern 
African region after the legal counsel of the African Union Commission ${ }^{48}$ highlighted the lack of balanced gender nominations. As a result of this challenge, $\mathrm{Mrs}$ Tujilane Rose Chizumla from Malawi was subsequently elected in January 2017. Mrs Imani Daud Aboud from Tanzania was similarly elected in July 2018 after the balanced gender condition was applied (African Court, 2018).

\section{The Special Rapporteur's mechanism on human rights defenders in Africa: A new era}

The mechanism of the Special Rapporteur on Human Rights Defenders in Africa remains one of the best examples of the work of the African Commission from a woman's perspective, since most of the time the mandate has been carried out by women. Its creation is based on two important factors. The first is linked to the many cases of serious violations of the rights of individuals who have chosen, individually or in association, to promote or protect human rights through advocacy and dialogue with stakeholders. These violations are found both in States Parties to the African Charter during times of conflict and in States Parties where there is relative peace. The second factor is the impetus provided by the creation of the United Nations Special Rapporteur on Human Rights Defenders, whose main objective was to effectively implement the United Nations Declaration on Human Rights Defenders (UNDHRD). ${ }^{49}$

The success of this United Nations mechanism depended on the joint efforts of all human rights defenders around the world, including those in Africa. Civil society actors organized the Johannesburg International Conference in 1998 as a first response to the implementation at the African regional level of the UNDHRD (Amnesty International, 1998). They created the Johannesburg Declaration and recommended to the African Commission that a special mechanism for African human rights defenders (HRDs) be established (Amnesty International, 1998). The Grand Baie Declaration followed in 1999, ${ }^{50}$ and African HRDs subsequently benefited from the Kigali Declaration in 2003. ${ }^{51}$ After the establishment of the focal point on HRDs in 2003, the special mechanism of the Special Rapporteur on Human Rights Defenders in Africa was established in June 2004 and adopted at the 35th Ordinary Session of the African Commission held in Banjul, Gambia (African Commission, n.d.b). The mandate of the Special Rapporteur on Human Rights Defenders in Africa includes an obligation to

seek, receive, examine, and act on information related to the situation of human rights defenders in Africa; submit ... [periodic] report[s] on the situation of human rights defenders in Africa; establish collaboration and dialogue with States Parties to the charter, national human rights institutions, human rights defenders, and other partners; develop and recommend strategies to better protect human rights defenders and follow up on these recommendations; and promote and raise awareness about the implementation of the Declaration of Human Rights Defenders in Africa.

(African Commission, n.d.b) 


\section{Reine Alapini-Gansou}

The first Special Rapporteur on Human Rights Defenders in Africa position, established in 2004, was held by a woman-Commissioner Jainaba Johm. ${ }^{52}$ Appointments for the Special Rapporteur are made according to the will and the availability of the commissioners during internal consultations. Since this mechanism was created in June 2004, it took some time to explore options for successors for Commissioner Jainaba Johm, whose term in the Commission was ending in 2005. The second mandate holder was also a woman-Commissioner Reine Alapini-Gansou, who held the position from 2005 to 2009 (International Service, 2011). Commissioner Alapini-Gansou transitioned to lead the African Commission as chairperson in 2009, and Commissioner Mohamed Khalfallah acted as Special Rapporteur in 2010 (International Service, 2011). The position was then taken over by Commissioner Lucy Asuagbor from 2010 to 2011 and again by Commissioner Alapini-Gansou from 2012 through 2017 (International Service, 2011). The current Special Rapporteur is Commissioner Rémy Ngoy Lumbu (African Commission, n.d.b). The achievements of the mechanism under the gender approach in this case, and the different challenges it has faced during these periods, were especially visible to the African Union community.

From 2005 to 2009, Commissioner Reine Alapini-Gansou carried out her mandate under the campaign Synergy with Stakeholders, which led to the creation of the Pan-African Network of Human Rights Defenders (HRDs) and the strengthening and establishment of regional networks of HRDs. ${ }^{53}$ Because of this continental networking, the actions of HRDs are increasingly effective, especially concerning the rights and protections of HRDs at risk. HRDs are often in conflict with state actors given the nature of their work, and their work is often subject to attacks and reprisals. These conflicts and attacks justified the extension of the mechanism's mandate to include issues related to reprisals under the terms of Resolution 273 adopted at the 55th Ordinary Session of the African Commission in 2014 in Luanda, Angola (African Commission, n.d.b).

The mechanism of the Special Rapporteur on Human Rights Defenders has been active since its creation. It has promoted communication through press releases; it has created urgent appeals procedures on allegations of rights violations of human rights defenders and has created a newsletter as an information tool for stakeholders. Strong resolutions have been adopted under pressure from the mechanism on reprisals against HRDs and the right to freedom of sexual orientation. As of today, about 30 resolutions have been created on behalf of the mechanism. ${ }^{54}$

While maintaining its overall mission to promote and protect the rights of HRDs, the mechanism has undertaken several studies in various fields on behalf of HRDs in Africa. Examples include studies on freedom of association, the situation of women HRDs in Africa, the guidelines and principles of human rights and terrorism in Africa, and the guidelines on freedom of association and assembly in Africa. ${ }^{55}$ Due to the mechanism's efforts, HRDs are recognized for their work and are increasingly called upon in the context of serious and massive human rights violations resulting from conflicts between States Parties and the African Charter. These activists are now deployed as part of human rights monitoring 
systems. The mechanism has supported a model law for recognizing HRDs in Africa for the benefit of States Parties to the African Charter. ${ }^{56}$

By carrying out their mandate with responsibility and commitment, the Special Rapporteurs have established the necessary collaboration between regional human rights bodies across Africa, Asia, Europe, and the Americas and the universal United Nations mechanism by launching periodic meetings now called "inter-mechanism meetings." ${ }^{\text {7 } 7}$ These meetings aim to strengthen all human rights mandates of HRDs through joint activities meant to promote and protect human rights.

Looking back at the African Commission's past and current situation with regard to women's representation in the body, the mechanisms have achieved success in sensitive areas like human rights, especially improving the protection of women's rights (Pretoria University, 2016). The two examples provided earlier concretely show how women can assume their responsibilities, meet their commitments, demonstrate their sense of duty, and assume their roles as leaders. These skills are also demonstrated in other cases of women's participation in the work of the Commission. Moreover, as of this writing, the African Commission is the first body within the African Union system to include more women and has best met the African Union's gender strategy.

Other bodies, like the African Court on Human and Peoples' Rights ${ }^{58}$ and the African Committee of Experts on the Rights and Welfare of the Child, ${ }^{59}$ are also improving with regard to women's representation. ${ }^{60}$ The high level of expertise required in international human rights law and in international justice may be one of the reasons why women's representation is improving in these various mechanisms, as with the active agenda for gender equality, women have better conditions and chances to seek professional qualification and thus are encouraged to build on their professional portfolios. Because women were denied those rights and spaces for so long, they now can see moving forward professionally as a valuable achievement. Building up a career for most women is not only a professional act but also an act of resistance and transformation taken with great enthusiasm. Further, the sense of sacrifice and the knowledge that the Special Rapporteur's function is temporary requires that the members of the ACHPR give the best of their time to serve human rights across the African continent. The women who have occupied these Rapporteur positions have had to make sacrifices while juggling their primary professional careers in their home countries and their personal obligations, often as caregivers of their immediate and extended families.

\section{Conclusion}

The foregoing discussion shows that the efforts to ensure women's presence in the African Commission are worthy of analysis, even if the risk faced by all human rights actors, including experts, activists, and HRDs, is very high. Implementation of international human rights law is not easy, especially when it is women who must help to achieve such an objective. Women embark on such tasks, often encouraged by their peers and States Parties in some respects; they are to be 
commended for crossing both socio-cultural and material barriers. Just because women are encouraged to take on these tasks does not mean that women's rights have been achieved; we do not have to accept the status quo knowing that the recognition of gender disparities underlying the concern for human rights always remains an ideal to strive for, like human rights themselves. Women's representation in the African Commission should be maintained and used as an example to achieve gender parity within all AU organs and within the institutions of domestic States Parties. More women are working hard to achieve their goals through their ambition to push for equality.

Things are changing, but there is still a lot to be done. As highlighted previously, the African Commission is currently composed of five men and six women. Women should continue to work together with their male colleagues to achieve the goals of the Commission and promote human rights across Africa. But much remains to be done to achieve the much-needed strengthening of women's substantive representation in the African Commission. As a recent victory, this representation is always subject to resistance from cultural traditions, for instance, but also from political interests; however, this resistance is a normal process. Social and political changes, especially those of high magnitude, pass through a moment of adaptation and face opposition on different levels exactly because those changes challenge the conventional power relations and privileged positions. For this reason, even if women's representation within the African Commission shows remarkable progress toward gender parity from when the Commission first started, it is necessary to strengthen and continue this progress to guarantee the continued and effective participation of women in the Commission's work and in mainstreaming the rights of women in Africa, thereby avoiding a regress in terms of the achievements already conquered. The three recommendations presented in the following sections reflect on that risk.

\section{The institutionalization of the gender question}

If gender equality is to be mainstreamed, this agenda must be reflected in political and judicial institutions. For example, as part of its action plan, the African Union has institutionalized gender equity in elections within the African system, thereby marking a progressive implementation of its gender equality plan. Further, on the African Union level, there are some mechanisms in place to institutionalize gender equity, such as the 2004 African Union Solemn Declaration on Gender Equality in Africa (SDGEA), where all the AU member states agreed to ratify the Maputo Protocol and to internalize the provisions of that document; and the Directorate of Women, Gender and Development (WGDD), which works within the AU to ensure that states are complying with the SDGEA and are promoting gender equality in the region (African Union, 2016b). The AU Strategy for Gender Equality and Women's Empowerment 2018-2028 has also been adopted to implement this policy (African Union, 2018). The African Union has also established the African Union Specialized Technical Committee on Gender Equality and Women's Empowerment in 2006 (African Union, 
2016b). It is an organization composed of African women (chosen based on representative criteria) and intended to serve as an advisory committee to the chairperson of the African Union Commission on women's rights-related issues (African Union, 2016b). These initiatives are essential in institutional terms, and they are important for maintaining the current trends to avoid the possibility that the progress will be slowed or stopped.

Political actors have to ensure gender equality, especially on the domestic level, since the strengthening of women's rights within the states reflects on the regional bodies such as the Commission and the African Union. Therefore, state leaders would do well to implement the gender agenda within their government plan by integrating gender perspectives in the ministries and in the national human rights institutions (the Maputo Protocol). For this integration, qualified women with backgrounds in human rights and experts in gender studies in these ministries are essential. Further, states can create ministries or government agencies specializing in women's rights and gender discrimination, such as the "Ministry of Equality" (Ministerio de Igualdad) created in Spain. This could be an effective way of incorporating these equality objectives into government actions and creating effective policies focused on women and girls. These are measures that could result in an irrevocable institutionalization of gender parity within the African system.

\section{Toward the necessary eradication of sociological fear}

Africa continues to carry the weight of certain cultural and social practices that infringe on women's rights. Among other things, the family and community environment in which women live and the gender-based expectations they face, such as the duty to serve at home and to be caregivers, are social and cultural barriers to women's advancement and contribute to their reservations when women are deciding whether to pursue leadership positions. States should act to overcome these stereotypes that are built into the culture and society. States may pass laws criminalizing acts of gender-based violence and other culturally harmful practices such as forced marriage and FGM while following up with effective investigation and prosecution. Additionally, it is important to repeal existing laws that make it difficult for women to exercise their reproductive rights and laws that hinder access to the right to property and inheritance for women.

It is impossible to discuss effective cultural changes without including education. Thus, it is essential to have an education system free of discriminatory ideologies that do not reinforce gender roles for young girls and boys. Instead, children can grow up learning that women and men should develop their lives in partnership and with equality. In this respect, girls should have access to schools and universities and be encouraged to attend at the same level as boys. It is essential to empower them with an emancipatory education. They will learn that they can and should lead their lives and make their own choices, including regarding when, how, or whether they want to constitute a family. 
At the nuclear and the extended family levels, men, husbands, fathers, and brothers reinforce particular roles for women through their daily behavior. Men's role in this system of discrimination highlights why any action addressing women and gender issues should involve men. Because many relationships between men and women are interdependent, men must act as women's allies. In this respect, continuous awareness-raising of men's duties, through campaigns and educational programs focused on men, will help reduce women's sociological fear and build a world in which the relationship between men and women can be based on collaboration rather than on exploitation and oppression. As the cause of women's representation in formal institutions progresses, male representatives and authorities should also see themselves as part of this cause to open the dialogue within the male community and with their partners about the need for equality. Men, therefore, support women in empowerment and in carrying the burden of their own liberation.

\section{The shadow of human rights-Creating a political culture of human rights}

Human rights remain the channel through which adversity—and often, violence by political actors - must be addressed. Because of this, making the choice to work in the field of human rights is difficult and fraught. Outside the academic and professional curriculum, African HRD women must make the difficult choice of bearing the actions of governments and political actors whose development agendas still disregard the need for human rights. The persistence of human rights violations, which is evident through conflicts in many States Parties to the African Charter, does not allow us to give up. Human rights violations in the context of African conflicts affect the population generally, but not equally. In these contexts, women and children are normally affected more intensely. The conflicts normally stress and worsen previous forms of gender-discriminatory patterns and create new forms of dangers to women and girls, such as sexual and physical abuse (African Union, 2016b). Because of this, women have historically had the most at stake and many reasons to participate in conflict resolution for peace through justice and reconciliation programs. It is important to comprehend the differences between the effects of these conflicts on women and on men to also address more appropriate solutions. Every transitional justice process must involve women. It is necessary to equip legal and political institutions with women to bring women's needs and perspectives to decision-making processes in states that are experiencing political transformation.

The scale of sexual crimes or crimes committed by minors and children in the context of armed conflicts is yet another factor necessitating women's participation in any justice and human rights processes. In this context, the involvement of female judges and commissioners would give a chance to the many women victims of sexual crimes, and of other serious and massive human rights violations, to make their voices heard. Special juries composed exclusively or predominantly of women are one interesting example that some human rights defenders have 
advocated for. Systemic discrimination that occurs within the justice institutions themselves, which are permeated with gender stereotypes and gender-discriminatory views regarding women, is a big challenge to guaranteeing accountability for sexual crimes.

As the majority of the victims of sexual violence, women face several challenges in the justice systems. Their statements are often treated as suspicious, and those responsible for the investigation and prosecution of cases tend not to believe women entirely or to ascribe less credibility to women's words, not uncommonly even blaming the victims themselves for the crime. Individuals tend to reproduce their prejudice in the analysis of the cases. Having lost confidence in the justice system, victims may end up not taking the crime to the legal field for fear of being misunderstood and humiliated. One way to address this issue in a credible and effective way would be to have a panel of women jury members, which would make victims feel more protected and provide the necessary compassion and sensitivity that such cases require. Moreover, a panel of women would, at least theoretically, be less inclined to misjudge victims of those crimes, and the result would be an institution more committed to the fair administration of justice.

The African Commission has been called upon to deal with a number of cases of serious human rights violations in recent years, including cases on genderbased discrimination and violence.$^{61}$ In this regard, the trend toward greater representation of women in the African Commission should be maintained so that these sorts of cases can be better addressed. In fact, as demonstrated in this chapter, it is impossible to talk about universalism in human rights without proper representation of human diversity; to achieve diversity, gender representation is essential because of the historical exclusion and oppression women have suffered. If we also recognize the vital role played by women in the African system, considering their work as commissioners of the African Human Rights Commission and as Special Rapporteurs, in addition to their participation in peace and security agendas, their presence in human rights bodies at the level of the African Commission should be a given.

\section{Notes}

1 Temporarily based in Addis Ababa, Ethiopia in November, 1987, the headquarters moved to Banjul, The Gambia in 1989 (African Commission, n.d.a). The African Commission is established under Article 30 of the African Charter (African Charter, 1981).

2 The International Commission of Jurists worked hard for the establishment of the African Commission and has remained an active NGO (African Commission, n.d.a).

3 These other regional human rights systems and documents include the 1950 European Convention on Human Rights and Fundamental Freedoms (Council of Europe, 1950); the Inter-American human rights system with the 1969 American Convention on Human Rights (Organization of American States, 1969); and the Asian system with the 1988 Asian Convention on Human Rights (Asian Human Rights, 1998).

4 Read La défense internationale des droits de l'homme by Jean-Luc Mathieu for more information (1998). 
5 The Charter contains 68 provisions addressing civil, political, economic, social, and cultural rights along with rights of solidarity (African Charter, 1981). The Charter is not structured in the same way as the Universal Declaration of Human Rights of 1948 (Universal Nations, 1948) or as the twin covenants of the International Covenant on Civil and Political Rights and the International Covenant on Economic, Social and Cultural Rights developed in 1966 (United Nations, 1966a, b) in that the third generation of community rights and solidarity is not specifically enumerated in the Charter.

6 See Articles 33 and 36 of the Charter (African Charter, 1981).

7 As part of its series of women's conferences, the United Nations 1995 Fourth World Conference on Women in Beijing was the final conference of the series (UN Women, n.d.c). Notably, the Beijing Conference produced the Beijing Declaration and Platform for Action, which was adopted by 189 different countries (UN Women, n.d.c). The documents serve as an "agenda for women's empowerment and [are] considered the key global policy document [s] on gender equality" (UN Women, n.d.c). Further, the follow-up activities to the Beijing Conference include reviews and appraisals every five years of the Platform for Action (UN Women, n.d.c). The most recent review was scheduled for March 2020, but aside from a procedural meeting that included adoption of the draft Political Declaration, all substantive debate and activities were postponed because of the COVID-19 pandemic (UN Women, n.d.b).

8 Article 42 of the African Charter sets out that the chairperson and vice-chairperson are elected for a two-year period and are eligible for re-election (African Charter, 1981).

9 Mrs. Duarte's expertise was recognized in 1995 when she was awarded the Council of Europe's North-South Prize for her "commitment to human rights, democracy and rule of law" (Council of Europe, n.d.b, c).

10 The Beijing Declaration and Platform for Action created policy recommendations to ensure equality for women. Notably, those documents identified women's under-representation in decision-making positions in all fields, including legal and diplomatic positions, and called on States Parties to work for better women's representation (United Nations, 1995). Since the African Commission was lacking in women's representation in its early years, it was slow to implement the Beijing recommendations.

11 Women representatives included Commissioners Angela Melo of Mozambique, Vera M. Chirwa of Malawi, Jainaba Johm of The Gambia, and Salamata Sawadogo of Burkina Faso (African Commission, n.d.b).

12 Female members from the 2002 session remained the same, with the addition of Sanji Monageng of Botswana, who first attended an ACHPR session in November 2003 (African Commission, n.d.b).

13 Commissioners Sawadogo, Melo, and Monageng remained, and Reine AlapiniGansou of Benin and Faith Pansy Tlakula of South Africa were added (African Commission, n.d.b).

14 Little information is available about the national processes for nominating candidates to the African Commission, and the Executive Council noted in 2011 that only nine candidates were nominated for five positions; since then, the Commission has recommended that each region nominate candidates in surplus of the number of available positions (Murray, 2019).

15 This majority was represented by new members Soyata Maiga of Mali, Zainabo Sylvie Kayitesi of Rwanda, and Catherine Dupe Atoki of Nigeria, along with returning Commissioners Alapini-Gansou, Monageng, Tlakula, and Melo (African Commission, n.d.b).

16 Commissioner Angela Melo was elected following Article 39 of the African Charter (African Charter, 1981). 
17 In 2011, Commissioners Alapini-Gansou and Tlakula were re-elected, and Commissioners Maya Sahil-Fadel, Med S. K. Kaggwa, and Pacifique Manirakiza were elected as new members (African Commission, n.d.b).

18 In 2013, Commissioners Yuen, Soyata Maiga, and Lucy Asuagbor were re-elected, and Commissioner Lawrence Murugu Mute was newly elected (African Commission, n.d.b).

19 Commissioner Kayitesi was re-elected, and Commissioners Jamesina E. L. King and Solomon A. Dersso were newly elected in 2015 (African Commission, n.d.b).

20 The newly elected members in 2017 included Commissioners Hatem Essaiem, Rémy Ngoy Lumbu, and Maria Teresa Manuela with Commissioner Maya Sahil-Fadel reelected (African Commission, n.d.b).

21 Meaning "everlasting life," or, in this case, to serve a life term (Decock, 2013, pp.159160).

22 Read Article 25 of the Maputo Protocol, which requires that states have a duty to provide remedies to women whose rights or freedoms have been violated (African Union, 2003). It follows, therefore, that if female candidates were not given the opportunity to run for elected positions, the states would have to provide a remedy.

23 Other international treaty bodies have encouraged equal representation. For example, the Rome Statute for the International Criminal Court in Article 36(8)(a) provides:

"The States Parties shall, in the selection of judges, take into account the need, within the membership of the Court, for:

(i) The representation of the principal legal systems of the world;

(ii) Equitable geographical representation; and

(iii) A fair representation of female and male judges" (International Criminal Court, 1998).

24 For example, in the case of the Maputo Protocol, 16 countries have signed but not ratified; even though the right to better gender representation is enshrined in this protocol, women's rights are being undermined by a lack of political will (Ayeni, 2016, p.309). States often have interests to share and negotiate, sometimes to the detriment of texts.

25 The Maputo Protocol has been described by the African Union Commission's Women, Gender and Development Directorate as "one of the most progressive legal instruments providing a comprehensive set of human rights for African women" (Women, Gender and Development, 2016, p.1). Articles in the Protocol point to equal representation of women during electoral processes and in the judicial and law enforcement arms of government (African Union, 2003).

26 The International Commission of Jurists (ICJ) is a human rights NGO created in 1952 (International Commission of Jurists, n.d.a) and currently has up to 60 prominent figures in the legal world, such as judges, lawyers, and law professors (International Commission of Jurists, n.d.b). Mary Robinson, the former president of Ireland and former United Nations High Commissioner for Human Rights, served as the ICJ president from 2008 until her successor took over at the end of January 2011 (International Commission of Jurists, 2011). The ICJ has consultative status with the Economic and Social Council of the United Nations (Economic and Social Council, 2018), the United Nations Educational, Scientific, and Cultural Organization (UNESCO, n.d.), the Council of Europe (Council of Europe, n.d.a), and the Organization of African Unity (Murray, 2007).

27 The technical support was especially prevalent in the context of the African Charter's redaction and the adoption of the African Commission's first Rules of Procedure in 1995 (Tolley, 2003).

28 See the list of participating NGOs in the prelude to the sessions of the African Commission (Network, 2020). The Open Society Initiative subsequently took over on many issues. 
29 As of 2021, the African Commission has granted observer status to NGOs that so desire from all over the world (African Commission, n.d.a). See resolution on Cooperation between the African Commission on Human and Peoples' Rights and NGOs having Observer Status with it-ACHPR/Res.30 (XXIV) 98 (African Commission, n.d.b). Although NGOs play an important role as observers with the African Commission, their power to bring suit against states in the African Court has recently been diminished. Rwanda, Tanzania, Côte d'Ivoire, and Benin have all withdrawn from Article 30(f) of the Protocol on the Statute of the African Court of Justice and Human Rights, leaving only six states that allow NGOs this access to the court (International Justice Resource Center, 2020).

30 Today, NGOs such as the International Federation for Human Rights (FIDH, 2019) or the Open Society Initiative can be found advocating at the African Union summits and African Commission sessions.

31 Article 38 of the ACHPR requires Commissioners to make an oath or "declaration to discharge their duties impartially and faithfully" (African Charter, 1981). This does not, however, require the members to discontinue their individual professions.

32 Many of these areas of expertise reflect the various Special Rapporteur and Working Group positions that many women commissioners have led or been a part of.

33 For example, Commissioner and Chairperson Reine Alapini-Gansou litigated constitutional cases in Benin and served as a lecturer researcher in criminal law and criminal procedure at the Benin National University of Abomey (International Criminal Court, 2015), and Commissioner and Chairperson Catherine Dupe Atoki similarly worked as a lawyer in private practice and as a senior lecturer at the State Polytechnic Kaduna in Nigeria (African Commission, n.d.a). Both these women also led extensive careers in human rights in addition to working with the African Commission and fulfilling their other responsibilities.

34 The Commission's Rules of Procedure specifically give the Commission the power to create any subsidiary mechanisms, such as Special Rapporteurs, Committees, and Working Groups, in Rule 23 (African Commission, 2010).

35 As of 2021, there are 13 special mechanisms: Special Rapporteur on Prisons and Conditions of Detention in Africa, 20th Ordinary Session (Kampala; September, 1996); Special Rapporteur on Rights of Women in Africa, 23rd Ordinary Session (Banjul; April, 1998); Working Group on Indigenous Populations/Communities in Africa, 28th Ordinary Session (Cotonou; November, 2000); Resolution on Guidelines and Measures to Prohibit and Prevent Torture and Sentences or Cruel, Inhuman or Degrading Treatment or Punishment in Africa, 32nd Ordinary Session (Banjul; October, 2002); Protection of Human Rights Defenders in Africa, 35th Ordinary Session (Banjul; May-June, 2004); Special Rapporteur on Freedom of Expression in Africa, 36th Ordinary Session (Dakar; November-December, 2004); Special Rapporteur on Refugees, Asylum Seekers and Displaced Persons in Africa, 35th Ordinary Session (Dakar; November-December, 2004); Economic, Social and Cultural Rights in Africa, 36th Ordinary Session (Dakar; NovemberDecember, 2004); Working Group on the Death Penalty and Extrajudicial, Summary or Arbitrary Executions in Africa, 38th Ordinary Session (Banjul; November-December, 2005); Working Group on Rights of Older Persons and People with Disabilities in Africa, 42nd Ordinary Session (Brazzaville; November, 2007); Working Group on Extractive Industries, Environment and Human Rights Violations in Africa, 46th Ordinary Session (Banjul; November, 2009); and Committee on the Protection of the Rights of People Living with HIV (PLHIV) and Those at Risk, Vulnerable to and Affected by HIV, 47th Ordinary Session (Banjul; May, 2010) (African Commission, n.d.c).

36 Recent resolutions by these special mechanisms can be found on the website of the African Commission (African Commission, n.d.c). 
37 For example, in Article 9.2, the Maputo Protocol encourages "increased and effective representation and participation of women at all levels of decision-making" as an international gender requirement (African Union, 2003).

38 See the compilation of documents drafted by the various mechanisms during the celebration of the 25th anniversary of the African Commission (African Commission, n.d.b).

39 The mandate has been renewed four times, the last time being in Resolution 154 of the 46th Ordinary Session (African Commission, n.d.c).

40 The Special Rapporteur on Prisons, Conditions of Detention and Policing in Africa is the oldest, created in 1996 (African Commission, n.d.c).

41 United Nations CEDAW was adopted in 1979; its implementation is evaluated annually by the Commission on Status of Women in connection with the committee of experts on the Committee on the Elimination of Discrimination against Women (United Nations Human Rights, n.d.; UN Women, n.d.a).

42 The Maputo Protocol was adopted pursuant to Article 66 of the African Charter, which allows for special protocols or agreements to supplement the African Charter (African Charter, 1981).

43 According to Article 26 of the Protocol to the African Charter on Human and Peoples' Rights on the Rights of Women in Africa, "States shall ensure the implementation of this Protocol at the national level, and in their periodic reports submitted in accordance with Article 62 of the African Charter, indicate the ... measures undertaken for the full realisation of the rights herein recognised" (African Union, 2003).

44 Commissioner Melo was first appointed at the 30th Ordinary Session of the African Commission in 2001 (African Commission, n.d.b) and was renewed at the 34th Session in 2003 (African Commission, n.d.b) and at the 38th Session in 2005 (African Commission, n.d.b).

45 Under Commissioner Soyata Maiga, two General Comments were adopted on Article 14 related to the right to health, including more specific steps for governments to implement regarding HIV prevention measures and access to reproductive care, including abortions (Durojaye, 2018). Commissioner Maiga also worked on drafting two additional General Comments before the end of her mandate, including one on the "equal sharing of property between husband and wife upon divorce" according to Article 7(d) and another jointly with the African Committee of Experts on the Rights and Welfare of the Child on child marriage related to Article 6(b) of the Protocol (Durojaye, 2018, p.5).

46 The Gender is My Agenda Campaign (GIMAC) has been active in organizing gender initiatives and convening the Pre-Summit Civil Society Organizations Consultative Meetings before the African Union summits, most recently in February 2020 (African Union, 2020).

47 Similar language is present throughout the protocols. For example, the Protocol on the Statute of the African Court of Justice and Human Rights requires "equitable gender representation in the [judicial] nomination process" in Article 5 and equitable gender representation in election of Judges in Article 7 (African Union, 2008). Article 14 in the Protocol establishing the African Court on Human and Peoples' Rights requires that during elections the Assembly shall "ensure that there is adequate gender representation" (African Union, 1998).

48 Josephine Dawuni notes that "the postponement of the election ... appears to have been a deliberate action on the part of the AU to make good on its gender parity promise" according to Articles 12 (2) and 14 (3) for the Protocol establishing the Court (Dawuni, 2017, para. 1).

49 Ms. Hina Jilani of Pakistan was the first appointed United Nations Special Representative on this issue following the 1998 adoption of the Declaration on the Right and Responsibility of Individuals, Groups and Organs of Society to Promote and Protect 
Universally Recognized Human Rights and Fundamental Freedoms; commonly called the United Nations Declaration on Human Rights Defenders (United Nations, 2000).

50 The Grand Baie Declaration and Plan of Action of 1999 was adopted during the First OAU Ministerial Conference on Human Rights (African Commission, 1999).

51 The Kigali Declaration of 2003 was adopted at the First African Union Ministerial Conference on Human Rights in Africa, held in Kigali, Rwanda (African Commission, 2003).

52 Commissioner Jainaba Johm was the focal point of this mechanism in 2003 before being appointed Special Rapporteur on Human Rights Defenders in 2004, but her term on the Commission ended soon after in 2005 (African Commission, n.d.b).

53 Currently, five subregional networks are members of the Pan-African Human Rights Defenders Network: Réseau Ouest Africain des Défenseurs des Droits Humains; DefendDefenders-East and Horn of Africa Human Rights Defenders Network; Réseau des Défenseurs des Droits Humains en Afrique Centrale; Cairo Institute for Human Rights Studies; and Southern African Human Rights Defenders Network (African Defenders, n.d.).

54 See the conclusions of the 63rd session of the African Commission, 20th anniversary of the 1998 UN Declaration on Human Rights Defenders.

55 See Compendium on the Legal Protection of Human Rights Defenders in Africa (Lumbu, 2018).

56 With the initiative of the International Human Rights Service.

57 For a reference to these meetings, see the report by Commissioner Alapini-Gansou (Alapini-Gansou, 2012) covering the 52nd Ordinary Session.

58 The Protocol establishing the Court was adopted in 1998 and entered into force in 2004; the first judges were sworn in during 2006. (African Court, 2020).

59 The Protocol establishing the Charter on the Rights and Welfare of the Child was adopted in 1990, came into force in November, 1990, and formed in 2001 (African Union, n.d.a).

60 To date, six women and five men are sitting judges at the African Court on Human and Peoples' Rights (African Court, 2020). Seven women also hold Special Rapporteur positions on the African Committee of Experts on the Rights and Welfare of the Child (ACERWC, n.d.).

61 For example, in Egyptian Initiative for Personal Rights and Interights, et al. v. Egypt, the African Commission used language from the African Charter to show that women who were sexually assaulted during a demonstration in 2005 had their rights to nondiscrimination as women violated (FIDH, 2019).

\section{Bibliography}

African Commission on Human and Peoples' Rights. (n.d.a). Home. https://www.achpr .org/home

African Commission on Human and Peoples' Rights. (n.d.b). Sessions. https://www.achpr .org/sessions

African Commission on Human and Peoples' Rights. (n.d.c). Special mechanisms. https:// www.achpr.org/specialmechanisms

African [Banjul] Charter on Human and Peoples' Rights. (1982). Adopted June 27, 1981, OAU Doc. CAB/LEG/67/3 rev. 5, 21 I.L.M. 58, entered into force October 21, 1986.

African Commission on Human and Peoples' Rights. (1999). Grand Bay (Mauritius) declaration and plan of action, 1999. https://www.achpr.org/legalinstruments/d etail $? \mathrm{id}=44$

African Commission on Human and Peoples' Rights. (2003). Kigali Declaration, 2003. https://www.achpr.org/legalinstruments/detail?id=39 
African Commission on Human and Peoples' Rights. (2010). Rules of Procedure of the African Commission on Human and Peoples' Rights. https://www.achpr.org/public/D ocument/file/English/Rules_of_Procedure_of_the_African_Commission_on_Human_ and_PeoplesRightsof2010_\%20Legal\%20Instruments\%20_\%20ACHPR.pdf

African Committee of Experts on the Rights and Welfare of the Child. (n.d.). Experts. https://reporting.acerwc.africa/CommitteeExperts

African Court on Human and Peoples' Rights. (2018, July 17). Three new judges elected to the African court on human and peoples' rights: VP Justice Ben Kioko re-elected for second terms [Press release]. http://www.african-court.org/en/index.php/news/press-re leases/item/245-three-new-judges-elected-to-the-african-court-on-human-and-peopl es-rights-vp-justice-ben-kioko-re-elected-for-second-term

African Court on Human and Peoples' Rights. (2020). Current judges. https://en.african -court.org/index.php/judges/current-judges

African defenders. (n.d.). Member networks. https://africandefenders.org/members/

African Union. (n.d.a). African Charter on the Rights and Welfare of the Child. https://au.int/ en/treaties/african-charter-rights-and-welfare-child

African Union. (n.d.b). Constitutive act. https://au.int/en/constitutive-act

African Union. (1998). Protocol to the African Charter on Human and Peoples' Rights on the Establishment of an African Court on Human and Peoples' Rights. https://au.int/sites/defa ult/files/treaties/36393-treaty-0019___protocol_to_the_african_charter_on_human_ and_peoplesrights_on_the_establishment_of_an_african_court_on_human_and_peo ples_rights_e.pdf

African Union. (2000). Constitutive Act of the African Union. https://au.int/sites/default/f iles/pages/34873-file-constitutiveact_en.pdf

African Union. (2003). Protocol to the African Charter on Human and Peoples' Rights on the Rights of Women in Africa. https://www.un.org/en/africa/osaa/pdf/au/protocol_right s_women_africa_2003.pdf

African Union. (2004). Solemn Declaration on Gender Equality in Africa. https://www.un. org/en/africa/osaa/pdf/au/declaration_gender_equality_2004.pdf

African Union. (2008). Protocol on the Statute of the African Court of Justice and Human Rights. https://www.african-court.org/en/images/Basic\%20Documents/ACJHR_Protoc ol.pdf

African Union. (2009). AU gender policy. African Union. https://www.un.org/en/africa/o saa/pdf/au/gender_policy_2009.pdf

African Union. (2016a). Executive Council Twenty-Eighth Ordinary Session: Decisions. https://au.int/sites/default/files/decisions/29513-ex_cl_dec_898_-_918_xxviii_e.pdf

African Union. (2016b). Women's Rights in Africa. https://www.ohchr.org/Documents/Iss ues/Women/WRGS/WomensRightsinAfrica_singlepages.pdf

African Union. (2018). AU Strategy for Gender Equality and Women's Empowerment: 2018-2028. https://au.int/sites/default/files/documents/36195-doc-au_strategy_for _gender_equality_womens_empowerment_2018-2028_report.pdf

African Union. (2020, February 3). 35th gender is my agenda campaign (GIMAC) civil society gender pre-summit. https://au.int/en/newsevents/20200203/35th-gender-my-ag enda-campaign-gimac-civil-society-gender-pre-summit

Alapini-Gansou, R. (2012). Report on the implementation of the mandate of the special rapporteur on human rights defenders in Africa of the African Commission on Human and Peoples' Rights. African Union. https://www.achpr.org/sessions/intersession?id=140

Amnesty International. (1998). All Africa Human Rights Defenders' Conference. https://ww w.amnesty.org/download/Documents/148000/afr010101998en.pdf 
Asian Human Rights Commission. (1998). Asian Human Rights Charter. https://www.ref world.org/pdfid/452678304.pdf

Ayeni, V.O. (2016). The Impact of the African Charter and the Maputo Protocol in Selected African States. Pretoria University Law Press (PULP).

Council of Europe. (n.d.a). Conference of INGOs. http://coe-ngo.org/\#/Ingos

Council of Europe. (n.d.b). FAQ. https://www.coe.int/en/web/north-south-centre/faq\# $\{\% 2227718377 \% 22:[9]\}$

Council of Europe. (n.d.c). Previous laureates of the North-South prize. https://www.coe .int/en/web/north-south-centre/previous-laureates-of-the-north-south-prize\#27717 772_27724221_True

Council of Europe, European Court of Human Rights. (1950). European convention on human rights. https://www.echr.coe.int/Pages/home.aspx?p=basictexts\&c

Dawuni, J. (2017, March 13). African women judges and gender parity on the African Court on Human and Peoples' Rights. LSE. https://blogs.lse.ac.uk/africaatlse/2017/03 /13/african-women-judges-and-gender-parity-on-the-african-court-on-human-andpeoples-rights/

Decock, W. (2013). Theologians and Contract Law: The Moral Transformation of the Ius Commune (ca. 1500-1650). Nijhoff

Durojaye, E. (2018). The special rapporteur on the rights of women in Africa (SRRWA) 2007-2015. Gender EB Behaviour, 16(1), 10700-10709.

Economic and Social Council. (2018). List of Non-Governmental Organizations in Consultative Status with the Economic and Social Council as of 1 September 2018. https:// undocs.org/E/2018/INF/5

Genti, Nos. (2012, September). Vera Duarte, por grandes causas, pela vida, pelas pessoas. http://nosgenti.com/vera-duarte-por-grandes-causas-pela-vida-e-pelas-pessoas

Gutto, S. (2001). The reform and renewal of the African regional human and peoples' rights system. African Human Rights Law Journal, 1(2), 175-184.

International Commission of Jurists. (n.d.a). Part one: 1952-1970. https://www.icj.org/ history/part-one-1952-1970/

International Commission of Jurists. (n.d.b). The commission. https://www.icj.org/ commission/

International Commission of Jurists. (2011, January 27). Pedro Nikken elected new ICJ president. https://www.icj.org/january-2011-pedro-nikken-is-elected-new-icj-president/

International Criminal Court. (1998). Rome Statute of the International Criminal Court. https://www.icc-cpi.int/resource-library/documents/rs-eng.pdf

International Criminal Court. (2015). Alapini Gansou, Reine (Benin): Curriculum Vitae. https://asp.icc-cpi.int/iccdocs/asp_docs/Elections/EJ2017/ICC-ASP-EJ2017-BEN-CVENG.pdf

International Federation for Human Rights. (n.d.). African Union. https://www.fidh.org/ en/international-advocacy/african-union

International Federation for Human Rights. (2019). The Impact of Litigation on Combating Sexual Violence and Its Consequences in Africa: Sharing Experience and Practical Advice. https://reliefweb.int/sites/reliefweb.int/files/resources/436237467-The-Impact-of-Lit igation-on-Combating-Sexual-Violence-and-its-Consequences-in-Africa.pdf

International Justice Resource Center. (2020, May 6). Benin and Côte d'Ivoire to withdraw individual access to African court. https://ijrcenter.org/2020/05/06/benin-a nd-cote-divoire-to-withdraw-individual-access-to-african-court/

International Service for Human Rights. (2011, February 17). Special rapporteurs. https:/ /www.ishr.ch/news/special-rapporteurs 
Lima-Neves, T.S. (n.d.). Duarte, Vera. Oxford African American Studies. https://doi.org/10 .1093/acref/9780195301731.013.50507

Lumbu, N. (2018). Compendium on the Legal Protection of Human Rights Defenders in Africa. Pretoria University Law Press. https://www.achpr.org/public/Document/file/English/en glish_chrd.pdf

Malmstrom, S. \& Oberleitner, G.. (1996). Africa. Netherlands Quarterly of Human Rights, 14(1), 92-96.

Mathieu, J. (1998). La défense internationale des droits de l'homme. Presses universitaires de France

Murray, R. (2007). Human Rights in Africa: From the OAU to the African Union. Cambridge University Press.

Murray, R. (2019). The African Charter on Human and Peoples' Rights: A Commentary. Oxford University Press.

Olsen, F. (1990). El sexo del derecho. In: D. Kairys (Ed.) \& Santoro, M. \& Courtis, C. (Trans.). The Politics of Law (pp. 452-467). Pantheon.

Open Society Initiative for Southern Africa (OSISA) and Oxfam. (2009). Strengthening Popular Participation in the African Union: A Guide to AU Structures and Processes. https://oi -files-d8-prod.s3.eu-west-2.amazonaws.com/s3fs-public/file_attachments/au-guide-eng.pdf

Organisation of African Unity. (1994). Chapter Seven Seventh Annual Activity Report of the African Commission 1993-1994. https://archives.au.int/bitstream/handle/123456789 /5365/7e\%20Rapport\%20Annuel_E.pdf?sequence=1\&isAllowed=y

Organization of American States. (1969). American Convention on Human Rights. http:// www.oas.org/dil/treaties_B-32_American_Convention_on_Human_Rights.pdf

Pretoria University Law Press. (2016). A Guide to the African Human Rights System. https:/ /www.corteidh.or.cr/tablas/31712.pdf

Tolley, H. (2003). The International Commission of Jurists: Global Advocates for Human Rights. University of Pennsylvania Press.

UN Women. (n.d.a). A brief history of the commission on the status of women. https:// www.unwomen.org/en/csw/brief-history

UN Women. (n.d.b). CSW64/Beijing+25 (2020). https://www.unwomen.org/en/csw/cs w64-2020

UN Women. (n.d.c). World conferences on women. https://www.unwomen.org/en/how -we-work/intergovernmental-support/world-conferences-on-women

UNESCO. (n.d.). List of NGOs in Official Partnership with UNESCO within the Framework of the Directives Concerning UNESCO's Partnership with Non-Governmental Organizations (36C/Res. 108). https://en.unesco.org/sites/default/files/list_of_ngos_in_official_par tnership_with_unesco_-_liste_des_ong_en_partenariat_officiel_avec_lunesco_-_feb_ 2020_0.pdf

United Nations. (1948). Universal Declaration of Human Rights. https://www.ohchr.org/ EN/UDHR/Documents/UDHR_Translations/eng.pdf

United Nations. (1966a). International Covenant on Civil and Political Rights. https://www .ohchr.org/Documents/ProfessionalInterest/ccpr.pdf

United Nations. (1966b). International Covenant on Economic, Social and Cultural Rights. https://www.ohchr.org/Documents/Professionallnterest/cescr.pdf

United Nations. (1995). Beijing Declaration and Platform for Action. https://www.un.org/en/ events/pastevents/pdfs/Beijing_Declaration_and_Platform_for_Action.pdf

United Nations. (2000, August 18). Secretary-General names Hina Jilani, Pakistan, as special representative on human rights defenders [Press release]. https://www.un.org/p ress/en/2000/20000818.sga743.doc.html 


\section{Reine Alapini-Gansou}

United Nations Human Rights Office of the High Commissioner. (n.d.). Committee on the elimination of discrimination against women. https:/www.ohchr.org/en/hrbodies/ cedaw/pages/cedawindex.aspx

Wandia, M. (2004, June 3). Rights of women in Africa: Launch of petition to the African Union. Pambazuka News. https://www.pambazuka.org/gender-minorities/rights-women -africa-launch-petition-african-union

Women \& Gender and Development Directorate. (2016). Maputo Protocol on Women's Rights: A Living Document for Women's Human Rights in Africa. https://au.int/sites/defa ult/files/documents/31520-doc-maputo_protocol_on_womens_rights_a_living_doc ument_for_womens_human_rights_in_africa_submitted_by_the_women_gender_and _development_directorate_wgdd_of_the_african_union_commission.pdf 